Proceedings

\title{
Ecological Analysis of Heat Pumps in Poland in Terms of Carbon Dioxide Emissions ${ }^{+}$
}

\author{
Sara Sewastianik ${ }^{1}$ and Andrzej Gajewski $2, *$ \\ 1 Students' Scientific Society “Heat Engineer", Bialystok University of Technology, Wiejska Street 45 A, \\ 15-351 Białystok, Poland; sa.sewastianik@vp.pl \\ 2 Department of HVAC, Bialystok University of Technology, Wiejska Street 45 A, 15-351 Białystok, Poland \\ * Correspondence: a.gajewski@pb.edu.pl; Tel.: +48-797-995-923 \\ + Presented at the 9th Innovations-Sustainability-Modernity-Openness Conference (ISMO'20), \\ Bialystok, Poland, 20-21 May 2020.
}

Published: 14 October 2020

\begin{abstract}
The purpose of this work is a comparison of indirect carbon dioxide emissions between the different heat pump types that operate in Polish climate conditions. This analysis embraces an air-water heat pump (ASHP), ground-water heat pump (GSHP), water-water heat pump (WSHP), and a WSHP with a separating heat exchanger (SHE) in the selected towns, one in each climatic zone in the country. The study starts from a computation of heat demand and electrical energy consumption in every hour of the heating season using temperature values taken from a typical meteorological year (TMY). Then, seasonal coefficient of performance (SCOP) values are determined, which enables an assessment of which kind of heat pump meets the European Union requirements in every location. Eventually, indirect $\mathrm{CO}_{2}$ emissions that are caused by electrical energy production are estimated for every heat pump in each location.
\end{abstract}

Keywords: heat pump; carbon dioxide emissions; ASHP; GSHP; WSHP

\section{Introduction}

Increasingly disturbing temperature rise gives a base for threatening forecasts, which forces countries and international institutions to reduce temperature increase. One of the remedial measures taken by the European Union (EU) is aspiration to energy production in climate neutrality way [1]. For this reason, the EU promotes the replacement of high-emission heat generators in the central heating systems by heat pumps. Heat pumps does not directly emit any pollutions to the atmosphere, but indirect emissions are done during generation of power necessary for their operation [2]. Due to their growing popularity and diversity in thermal reservoirs or operating parameters, the European Commission introduced regulations that specify the minimum value of the seasonal coefficient of performance (SCOP) [3]. The purpose of this work is a comparison between indirect carbon dioxide emissions values for different types of heat pumps in Polish climate conditions.

\section{Material and Methods}

There are analyzed heat pumps in respect of 4 types of thermal reservoirs that are freely available on the market: an air to water heat pump (ASHP), ground to water heat pump (GSHP), water to water heat pump (WSHP) and a water to water pump. The operation of WSHP can be supported by the separating heat exchanger (WSHP + separating heat exchanger (SHE)). The devices will be the only heat generator in a detached house with a designed heat load $12 \mathrm{~kW}$ in five selected locations, one in every Polish climatic zone: Szczecin, Poznań, Łódź, Białystok, Zakopane. Outside temperature values 
are taken from a typical meteorological year (TMY) in each town, which seems to be the best approximation of the climatic conditions.

Since heating degree days (HDDs) and the average monthly outside temperature are used in the analysis as the climatic factors, it must be assumed that outside temperature is constant all month. Due to the fact that the COP depends on outdoor temperature and the dependence is not linear, such averageness may seem too far. Therefore, it was decided to consider the second temperature variant assuming that the average minimum temperature value equals the difference between the average monthly temperature value and half of the monthly amplitude value. These variants will be marked with the symbols ' $\mathrm{I}$ ' and ' $\mathrm{II}$ ', respectively.

At the initial stage of the analysis, the temperature values of the lower sources were determined. Temperature values for ASHP are equal to outer temperature. In the variant of GSHP, it is necessary to determine a soil temperature profile, which is done using the Baggs formula modified by the team led by Oleśkowicz-Popiel [4] for the Northern Hemisphere. In the case of the WSHP pump, the groundwater temperature value is needed as the groundwater basin is a lower heat source. These values are obtained from the relation described by Kowalski [5]. If WSHP had to be separated from the groundwater with SHE, a brine temperature decrease of $2{ }^{\circ} \mathrm{C}$ is assumed.

Further calculations of COP and SCOP values are based on the algorithms of applicable European standards [6,7].

Eventually, the indirect carbon dioxide emissions are determined for each system at every location. To do it, an algorithm, which is derived by Gajewski et al. [8], is used.

\section{Results}

The results of the analysis are presented in the full text of the publication. They compare the SCOP values determined with the obligatory EU regulations as well as the carbon dioxide emission values between the analyzed technological models.

Author Contributions: S.S. and A.G. created a calculation algorithm. S.S. did the computations of SCOP, A.G. did the computations of emissions, and S.S. and A.G. analyzed the data and wrote the paper. All authors have read and agreed to the published version of the manuscript.

Acknowledgments: The paper was prepared at Students' Scientific Society "Heat Engineer" at Bialystok University of Technology and was financed by this university. The research was carried out at Bialystok University of Technology at the Department of HVAC Engineering as the project WZ/WBiIŚ/4/2019 and was subsidised by the Ministry of Science and Higher Education of the Republic of Poland from funding for statutory $R \& D$ activities. The paper was prepared using equipment which was purchased thanks to either "INNO-EKO$\mathrm{TECH}^{\prime \prime}$ Innovative research and didactic center for alternative energy sources, energy efficient construction and environmental protection - project implemented by the Technical University of Bialystok (PB), co-funded by the European Union through the European Regional Development Fund under the Programme Infrastructure and Environment or "Research on the efficacy of active and passive methods of improving the energy efficiency of the infrastructure with the use of renewable energy sources" - project was co-financed by the European Regional Development Fund under the Regional Operational Programme of the Podlaskie Voivodship for the years 20072013.

Conflicts of Interest: The founding sponsors had no role in the design of the study; in the collection, analyses, or interpretation of data; in the writing of the manuscript; or in the decision to publish the results.

\section{References}

1. European Commission, Directorate-General for Climate Action. Communication from The Commission to The European Parliament, The European Council, The Council, The European Economic and Social Committee, The Committee of The Regions and The European Investment Bank: A Clean Planet for all A European Strategic LongTerm Vision for a Prosperous, Modern, Competitive and Climate Neutral Economy; Document 52018DC0773; European Commission: Brussels, Belgium, 2018.

2. Carvalho, A.; Mendrinos, D.; De Almeida, A.T. Ground source heat pump carbon emissions and primary energy reduction potential for heating in buildings in Europe-Results of a case study in Portugal. Renew. Sustain. Energy Rev. 2015, 45, 755-768, doi:10.1016/j.rser.2015.02.034. 
3. European Parliament; Council of the European Union. Directive 2009/28/EC of the European Parliament and of The Council of 23 April 2009 on the promotion of the use of energy from renewable sources and amending and subsequently repealing Directives 2001/77/EC and 2003/30/EC. Off. J. Eur. Union 2009, 140, $16-62$.

4. Oleśkowicz-Popiel, C.; Wojtkowiak, J.; Prętka, I. Effect of surface cover on ground temperature season's fluctuations. Found. Civ. Environ. Eng. 2002, 2, 151-164.

5. Kowalski, J. Hydrogeology with Basic Geology; Uniwersytetu Przyrodniczego we Wrocławiu: Wroclaw, Poland, 2007; pp. 106-107. ISBN 978-83-60574-14-0.

6. Energy Performance of Buildings-Method of Calculation of the Design Heat Load-Part 1: Space Heating Load, Module M3-3; PN-EN 12831-1:2017-08; Polish Committee for Standardization: Warsaw, Poland, 2017.

7. Air Conditioners, Chillers for Liquid Cooling and Heat Pumps with Electrically Driven Compressors, for Heating and Cooling Rooms-Testing and Evaluation Part Load Conditions and Calculation of Seasonal Capacity; PN-EN 14825:2019-03; The Polish Standardization Committee: Warsaw, Poland, 2019.

8. Gajewski, A.; Siergiejuk, J.; Szulborski, K. Carbon dioxide emission while heating in selected European countries. Energy Build. 2013, 65, 197-204, doi:10.1016/j.enbuild.2013.05.042.

(C) 2020 by the authors. Licensee MDPI, Basel, Switzerland. This article is an open access article distributed under the terms and conditions of the Creative Commons Attribution (CC BY) license (http://creativecommons.org/licenses/by/4.0/). 